\title{
THE TECHNOLOGY OF INDEPENDENT CONTENT PRODUCTION - BRAVI
}

Chair: Celso Araujo- Director Cinema/SET- Director LINK Multisserviços

Eletroeletrônicos

Co-chair: ESDRAS MIRANDA DE ARAÚJO - Northeast regional director / SET Technical and Operational Manager / Jangadeiro de Comunicação..

The independent content production is increasingly present in various display modes. And only an excellent script, direction and actors are not enough for the success of an audiovisual work. In this panel producers will discuss the technological challenges for the production and delivery of content in multiple screens.

- Speaker: Tiago Mello - Partner - Boutique Filmes

- Speaker: Sabrina Nudeliman Wagon - Diretora e Co-fundadora da ELO COMPANY

- Speaker: Marcio Yatsuda - Presidente da Movioca Content House

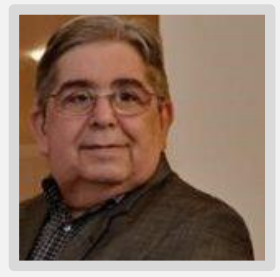

Celso Araujo- Director Cinema/SET- Director LINK Multisserviços Eletroeletrônicos

He joined TV Globo in 1973, where he worked for 40 years at the Central Globo de Engenharia, in Rio de Janeiro. He spent more than 12 years in maintenance, during which he had the opportunity for development in various sectors of the television maintenance, such as cameras, lenses, video, audio, switchers, routers, and even the management of systems and crews for production operations in sporting events, shows, World Cup and Olympics. Since 2013 acting as Entrepreneur, Business Consultant in the area of TV Technology and providing Seminars and Workshops with SET at its regional events, to the IAV (Audiovisual and Video Institute of São Paulo). 


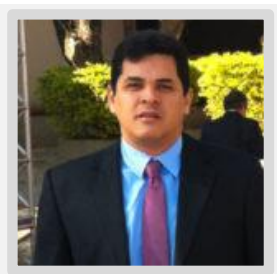

\section{ESDRAS MIRANDA DE ARAÚJO - Northeast regional director / SET - Technical and Operational Manager / Jangadeiro de Comunicação..}

He holds a degree in Electrical Engineering (Electronics), a graduate degree in Maintenance Management from the Polytechnic University of Pernambuco (UPE); and a graduate degree in business management from the Getúlio Vargas Foundation (FGV). He began his broadcasting activities in 1994 in FM and TV Tribuna (a BAND group affiliate in the state of Pernambuco). In 1999, he witnessed the birth and implementation of TV Guararapes (a BAND group affiliate in the state of Pernambuco). In 2003, he took over the Technical and Operations Division of the AM / FM Radio Club in Pernambuco. He is currently the Technical and Operations Manager of the Jangadeiro Communication System, with two TV stations affiliated to SBT and BAND (located in the state of Ceará) and of the Jangadeiro Radio System consisting of 8 FM broadcasters.

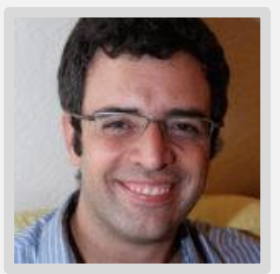

\section{Tiago Mello - Partner - Boutique Filmes}

Executive Producer of the series 3\%, the first original series by Netflix in Brazil. Co-creator and executive producer of the series "Zoo da Zu" (nominated for the 2015 International Emmy Awards, Discovery Kids), "Extraordinary Experiments" (Cartoon Network) and the cartoon S.O.S Fada Manu" (Gloob). Also responsible for the executive production of Gigantes do Brasil - Giants of Brazil (a fiction co-production with the History Channel), Cinelab (NBC Universal), Lowrider Brasil (Discovery Channel), A Grande Luta, series (HBO), among others works. Tiago Mello was responsible for the Escola Pra Cachorro (Doggy Day School) (TV Cultura/Nickelodeon/TV Ontario), one of the first co-productions between Brazil and Canada. With TV Globo and Cartoon Network, he was at the command of the animated series, "Sitio do Picapau Amarelo" (Yellow Woodpecker Farm). He was also creator and producer of "Julie e os Fantasmas" (Julie and the Phantoms) (Band/ Nickelodeon), nominated for the 2012 International Emmy Awards. As Executive Producer, he also produced the series Descolados (MTV) and Brilhante (Brilhante F.C.) (TV Brasil)

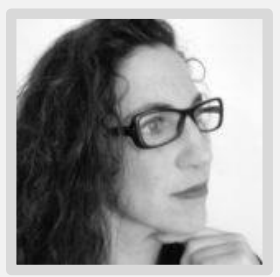

\section{Sabrina Nudeliman Wagon - Diretora e Co-fundadora da ELO COMPANY}

Extensive experience in audiovisual distribution and programming in Brazil and overseas. Holds a degree in Business Administration, with a specialization in communication and leadership, and strategic consulting experience at McKinsey. She has taught classes at the Getulio Vargas Foundation, FAAP and others. She has also given talks at the Cannes Film Festival about audiovisual distribution audiovisual, been part of the jury and pitching at the São Paulo Secretariat, TV Cultura and has drawn up cultural/social projects.

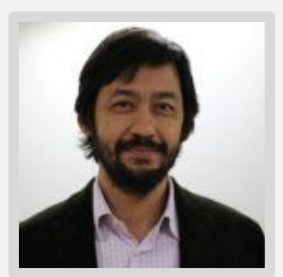

\section{Marcio Yatsuda - Presidente da Movioca Content House}

President of Movioca Content House, TV and cinema producer specializing in branded content and storytelling and a professor at the Academia Internacional de Cinema, São Paulo. Holds a degree in applied and computer mathematics from Unicamp, and several specializations in Administration, Executive Production Leadership and People Management. Was co-founder and president of Kaizen, an IT integration company, from 1996 to 2012, elected the "Best IT \& Telecom Company to Work for in Brazil" by "The Great Place to Work Institute" in 2007, having been acquired in 2010 by Chilean company, Sonda IT, Latin America's largest IT company. With extensive experience in 
SET EXPO PROCEEDINGS - SETEP v. 3

(C) 2017 SET - Brazilian Society of Television Engineering / ISSN (Print): 2447-0481/ ISSN (Online): 2447-049X

international business, in addition to Movioca, he is an investor and adviser to MW8 Soluções, a technology company, and works as an adviser to other companies..

Cite this article:

Araújo, C., Miranda, E., Mello, T., Wagon, S. N. and Yatsuda, M.; 2017. The Technology of

Independent Content Production - BRAVI. ISSN Print: 2447-0481. ISSN Online: 2447-049X. v.3.

doi: 10.18580/setep.2017.20. Web Link: http://dx.doi.org/10.18580/setep.2017.20 